\title{
Microbial growth kinetics: a historical perspective
}

\author{
Holger W. Jannasch ${ }^{1} \&$ Thomas Egli ${ }^{2}$ \\ ${ }^{1}$ Woods Hole Oceanographic Institution, Woods Hole, Ma 02543, U.S.A.; ${ }^{2}$ Swiss Federal Institute for Envi. \\ ronmental Science and Technology (EAWAG), CH-8600 Dübendorf, Switzerland
}

\begin{abstract}
Growth is the expression par excellence of the dynamic nature of living organisms. Among the general methods available for the scientific investigation of dynamic phenomena, the most useful ones are those that deal with kinetic aspects.

Kinetic investigations on cultures of micro-organisms are eminently suited for establishing relationships between growth and environmental factors, especially the nature and amount of nutrients. C. B. van Niel (1949)

The study of the growth of bacterial cultures does not constitute a specialised subject of branch of research: it is the basic method of Microbiology.

Monod (1949)
\end{abstract}

Key words: growth kinetics, history, microorganisms, chemostat

\section{Introduction}

Half a century's research has shown convincingly that growth kinetics has become an indispensable tool in the physiology, genetics, ecology and biotechnology of micro-organisms. Its wide-spread usefulness is based on its fundamental character, technically versatile applications and, ultimately, the sheer intellectual pleasure in dealing with its theoretical and practical challenges. Hinshelwood (1946) was probably the first one to compare boldly chemical reaction kinetics with that of microbial growth: "Chemical reactions have long been studied in isolation: in a cell these reactions occur in a co-ordinated manner, and in particular the autosynthetic process assumes a dominant role. The question whether any of the modes of thought and work to which the chemist is accustomed in dealing with inanimate systems help in understanding the behaviour of the living cell is one which must be asked unless the traditional method of proceeding from the known to the unknown is abandoned. If the answer is negative Nature will not hesitate to give it, but it is better to be put in one's place by her than by any other authority."

Today physical as well as chemical aspects involved in microbial growth kinetics are very much integrated into biological thinking so that Hinshelwood's question appears to be answered to the positive. His wording 'autosynthesis', can be assumed to be identical with today's term autocatalysis, i.e. a catalytic activity that increases in parallel with growth or enzyme synthesis. This principle must have been a major factor that led to the renaissance of interest in microbial growth kinetics in the early 1950 s, primarily and effectively mediated by the development of continuous culture systems toward the birth of the well defined chemostat.

Before, however, discussing these more recent developments, it is necessary, in a brief retrospect, to realise that it took more than two centuries after the discovery of the 'animalcules' by Antonie van Leeuwenhoek in 1675 (Dobell 1932) until the first quantitative description of microbial growth was published (Buchner et al. 1887; Ward 1895; Müller 1895). Using the 'hanging drop' method Ward (1895) determined doubling times of bacteria microscopically and described a rudimentary growth curve. Furthermore, he reported in this pioneering study that various environmental factors, such as temperature, nature and concentration of food, oxygen, light from the violet end of the spectrum as well as the addition of antiseptic substances influenced growth of the culture. Some twenty five years 
later the different stages of bacterial growth in batch culture were recognised, as a rule, to be perfectly predictable and reproducible. The first review on the subject was published by Buchanan (1918). During the next twenty years the quantitative description of microbial growth was dominated by Liebig's law, i.e. that the total bacterial crop produced is determined by the nature and critical 'minimum' concentration of one single nutrient (Stephenson 1949). Furthermore, much effort was spent to study the variability of the 'latent' (lag) phase of growth as reviewed by Winslow \& Walker (1939). Then, starting with Monod's thesis in 1942, microbial growth kinetics matured into an area of research in its own right as manifested in the mottoes heading this article.

Far from being presented here by professional historians, the general emphasis and the selective description of early developments of microbial growth kinetics are based on personal experiences by one of us (HWJ) and concentrates on the 'golden age' of the ascent of the steady-state-attaining continuous culture system, the chemostat, in the 1950 s and early 1960s. We will emphasise the ecological point of view as the most general approach from which all others - the biochemical/metabolic, genetic/molecular, and the technical/economic - can be derived. Furthermore, we will discuss the central question of the relation between growth rate and nutrient concentration, demonstrating thereby that microbial growth kinetics is not a closed book but that many fundamental questions are still unanswered.

\section{Continuous culture and microbial growth kinetics}

The early successful developments in the continuous cultivation of microbial cultures were not driven by theoretical or ecological considerations but simply by the practical necessities of how to obtain a large biomass of metabolically uniform cells, or how to select for mutants in a growing culture. The Czech school of industrial microbiology in Prague had been leading in continuous culture applications, an area we would put today in the category of biotechnology. This fact was acknowledged by choosing Prague to be the site of the first in a series of international symposia on the continuous cultivation of microorganisms (Málek 1958) by the then still very small international community interested in microbial growth kinetics.

It was, therefore, ironic that the rather simple principle of the chemostat was first mathematically conceived and technically described simultaneously and independently by Novick \& Szilard in the USA (1950) and by Monod (1950) in France. Monod had already published the ground work on bacterial growth in his thesis in 1942, but did not arrive at the principle of the steady state attaining continuous culture, the 'bactogen', until eight years later. His goal had been the maximum production of Escherichia coli cells, all grown at the same rate and having the same biochemical/enzymatic composition and activities. To the physicists Novick \& Szilard $(1950 a, 1950 b)$ the steady state equilibrium attainable in continuous culture of microorganisms, which they termed 'chemostat', and the mathematical possibilities to trace population changes, offered a chance to study the rate of mutations.

From the late 1950s to the mid-1960s microbial growth kinetics went through its 'exponential growth' period when the major capabilities and microbial phenomena of the continuous cultivation were discovered and defined in rapid succession. This is evident from the series of symposia held in Prague in 1958, London in 1960, again Prague in 1962, and Porton (England) in 1967. In the United States the initiative was taken up by a division 'Microbial and Biochemical Technology' of the American Chemical Society with regular meeting sessions on the continuous culture of microorganisms starting during the early 1960 s. Unfortunately there were no efforts in joint publications documenting these early developments in the U.S. In addition to the above symposia volumes, the Prague group (I. Málek, J. Hospodka, Z. Fencl, K. Beran and J. Ričica) undertook to prepare regular annual, later biannual, reviews on progress in the area of 'Continuous cultivation of microorganisms' in the journal Folia Microbiologia from 1959 to 1973 . These well organised overviews, together with the above mentioned symposia volumes, contain a wealth of original ideas. Most of them became the basis of sepa- 
rate areas of research or technical applications, others are still waiting to be exploited, but all of them reflect the excitement of this early but highly productive phase in the development of microbial growth kinetics.

Here is an example. The first symposium (Málek 1958) includes a discussion section during which the biochemical composition and 'physiological state' of bacterial cells harvested at various growth rates were debated. Solving the inherent difficulty of obtaining cell material grown at maximum rate near the washout point, Novick suggests to feed a chemostat, run at the dilution rate of maximum cell production (less than maximum growth rate), into a second vessel run slightly beyond the critical dilution rate (washout point). This allows one not only to harvest large quantities of cells grown at maximum rate under defined physico-chemical conditions in a continuous system, but also to determine the maximum growth rate with great accuracy by deducting the washout rate from the dilution rate (Novick, in Málek 1958, p. 394-395; Jannasch 1969).

The 'Porton group' under Herbert has to be given credit for making microbial growth kinetics in batch and continuous culture widely accessible to microbiologists by describing it mathematically on the basis of Monod's and Novick/Szilard's very simple and workable 'data fitting' Michaelis-Menten equation and by limiting the definition of growth parameters to the most essential ones (Herbert et al. 1956; Herbert 1958; Powell et al. 1967; Tempest 1970). Being widely read and easily understood, they nearly accomplished a common usage of the kinetic terminology at an international level, as suggested in Fencl's (1963) article on a uniform system of basic symbols for continuous cultivation of microorganisms. Furthermore, Herbert's introduction of a classification of the then various types of homo- and heterocontinuous culture systems and their specific characteristics (Herbert 1961a) and Málek \& Fencl's (1966) technically oriented book with contributions of the entire Czech group were very conducive for spreading the word. Perret's (1960) stimulating paper introduces the steady state attaining 'expanding' closed culture system demonstrating that, if complete mixing can be sustained, large subsamples from chemostat cultures can be taken with- out disturbing steady state conditions. Summarising the accomplishments of those years, there are three useful books: Pirt's general treatise on principles of microbe and cell cultivation, the more genetically oriented introduction to continuous culture by Kubitschek (1970), and Veldkamp's brief treatise (1976) emphasising physiology and ecology.

Sacrificing practicality, many authors around that time attempted to amend the general growth equation with factors considering maintenance metabolism (Marr et al. 1963; Pirt 1965; Powell 1967), a yield coefficient (Lamanna 1963; Malette 1963; Ričica 1966), cell viability (Tempest et al.1967), population density and starter populations (Contois 1959, Jannasch 1965), distribution of cell ages (Beran et al. 1967), storage products (Wilkinson \& Munro 1967). By incorporating such parameters either individually or in toto they tried to design optimal or universal growth equations. The latter has been elusive but the discussion on amending the mathematical expression of growth processes is still actively pursued. The particular problems involving the basic relationship between growth rate and substrate concentration are so central to microbial growth kinetics that we have decided to discuss it specifically in the second part of this article.

The main emphases in the early days of microbial growth kinetics in continuous culture were on resolving the typical batch culture phenomena, e.g., the lag-phase (Lamanna \& Malette 1959), the complex changes of cell growth and cell division rates resulting in the change of cell sizes, chemical composition and DNA/RNA content (Kjeldgaard et al. 1958; Schaechter et al. 1958; Rosenberger \& Elsden 1960, Herbert 1961b; Dean \& Rogers 1967), the briefness or absence of a physiological steady state in a closed culture system (Perret 1960), and the onset of enzyme synthesis characteristic for the stationary phase (Magasanik et al. 1959; Monod 1959; Pardee 1961). Furthermore, it required the chemostat to study particular regulation mechanisms in $E$. coli during the synthesis of tryptophane (Novick \& Szilard 1958) and to discover the phenomenon of de-repression (in the regulation of ornithine transcarbamylase; Gorini \& Maas 1957; Gorini 1960). Bauchop \& Elsden (1960) demonstrated the absence of repression in arginine utilisation at low lev- 
els of glucose as the limiting substrate during steady state growth in the chemostat.

Next to the chemostat-type continuous culture, two more systems were actively developed during those years but should be mentioned here just in passing: synchronous culture and the turbidostat. While steady state chemostat cultures contain cells of various ages, enforced and maintained synchronisation (Campbell 1957; Williamson \& Scopes 1961) allows the harvesting of cells of equal ages in order to study, for instance, DNA synthesis (Lark 1960 ) or enzyme synthesis during the course of the cell cycle (Abbo \& Pardee 1960; Schmidt \& King 1961). In chemostat cultures of photosynthetic microorganisms, growth might not be limited by a substrate contained in the medium but by light, the growth limiting quantity of which is independent of the dilution rate but affected by population density (Myers \& Clark1944; Bryson 1952; Goldman 1977). Under these circumstances, therefore, the flow of medium is better regulated nephelometrically, e.g. by a photo cell. The difference between the dilution rate regulated chemostat and the photo cell regulated turbidostat is also reflected by the fact that the former works best in the range of $K_{s}$ selection, the latter in the range of $\mu_{\mathrm{m}}$ selection.

One of the authors (HWJ) owes his introduction to the then brand new 'homocontinuous' culture kinetics to N. Pfennig during the late 1950s. Many lively discussions and most fruitful co-operation resulted in a rather extensive essay (Pfennig \& Jannasch 1962) which became the starting point for continuous culture applications in, what would today be termed, 'ecological' or 'environmental' microbiology. The new techniques not only allowed to obtain experimentally enforced 'steady state' conditions, but also 'transition states' in systems ranging from single stage homocontinuous pure cultures to multi-stage heterocontinuous mixed cultures. These new approaches offered most intriguing experimental possibilities to study natural microbial processes with increasing complexity.

\section{Homocontinuous systems}

The establishment of a steady state of microbial growth in a single stage pure culture chemostat, in which the dilution rate does not exceed the maximum growth rate, allows to remove experimentally the time factor in biochemical, physiological and genetic studies. Many interesting results were inadvertently obtained when data deviated from the theoretically and mathematically predicted pattern. The constant steady state population densities did not always occur where and when they should have. Due to imperfect mixing or to wall growth, for instance, the wash-out of cells from a chemostat, run at dilution rates higher than the maximum growth rate, does not necessarily occur at the critical dilution rate, etc. Several of such inconsistencies could be explained by 'apparatus effects' (Herbert et al. 1956; Herbert 1958). One, however, had a different cause and, because of its interest in ecology, should be briefly recounted in the following.

The ability of microorganisms to grow in a highly dilute medium appears to be an important physiological trait for aquatic bacteria. The chemostat theoretically permits the growth of bacteria at diminishing culture densities, keeping all other parameters constant (Jannasch \& Mateles 1974). All that is experimentally required is to wait for the establishment of steady state conditions of the population, and then shift over to a reservoir of the same medium but with a lower concentration of the growth limiting source of carbon and energy $\left(\mathrm{S}_{0}\right)$. A shift toward lower constant population densities was indeed observed but at lower levels than expected. As a corollary, with further decreases of the substrate concentration $\left(\mathrm{S}_{0}\right)$ washout occurred at an unexpectedly high concentration of $S_{0}$. Although everything, except for $S_{0}$, remained constant, it appeared that some other and unknown factor had become growth limiting: the population density itself or the ability of the total cell population to lower the redox potential of the medium to a level that became critical for sustaining the growth rate under the given condition of aeration. Adding ascorbic acid to the medium or lowering the amount of oxygen in the aeration gas restored (not all of) the growth limitation by the carbon source. In other words, in the presence of ascorbic acid, or lower oxygen concentration in the aerating gas mixture, the 
organisms could be grown at lower population densities (Jannasch \& Mateles 1974).

These observations have interesting implications for bacterial activities in the pelagic deep ocean which constitutes $75 \%$ of our planet's biosphere by volume, i.e. the seawater and seafloor below a depth of $1000 \mathrm{~m}$. A high oxidative potential, which occurs throughout such water bodies, where the oxygen consumption is lower than oxygen supply by currents and diffusion, may prevent the utilisation of available growth limiting carbon sources below a certain threshold level. The presence of viable bacteria indicates that they are controlling this threshold level. They will and can grow only when the limiting substrate concentration (mostly organic carbon) rises above the threshold level. The classical notion of the high total quantities of gold at unexploitable concentrations in the huge amount of seawater of the world oceans can be taken to be analogous to the large total quantities of dissolved marine organic matter, present at an equally unexploitable but microbially determined threshold level.

The concept of threshold concentrations of growth limiting substrates also helps to understand the frequent need for 'starter populations' to initiate growth under suboptimal conditions (Jannasch 1969). In order to overcome such unfavourable growth conditions, a 'sacrificial' amount of cells might be required, a lag phase phenomenon which is frequently observed in batch culture systems. In the same fashion as homocontinuous culture of microorganisms has been useful in fine-tuning the effect of oxygen levels or the redox potential on growth, it can be applied for the study of other factors that are undetectable or difficult to detect in the ever-changing growth conditions of batch culture systems. Dagley \& Hinshelwood (1938) discovered the growth limiting role of $\mathrm{CO}_{2}$ when they found that the latter was removed by the aerating gas in cultures of heterotrophic bacteria. This effect was overcome at high cell densities where cultures were able to produce a sufficient amount of $\mathrm{CO}_{2}$ to sustain growth. Contributions of $\mathrm{CO}_{2}$ and materials lowering the redox potential cannot be easily observed by growing cells in well aerated media in batch cultures which are commonly run at much higher populations densities than those attainable in the chemostat, except possibly as part of the lag producing phenomena.

If a homocontinuous culture system is inoculated with two or more organisms that differ by their growth responses, in principal, and according to Novick \& Szilard's selective enrichment of mutants, the fastest growing organisms will displace all others. This type of enrichment culture can be used for separating two organisms growing on the same medium but differing ever so slightly by their efficiency of substrate utilisation (Jannasch 1967), by the temperature dependency of their growth rates (Harder \& Veldkamp 1971) or by their obligately or facultatively chemolithotrophic metabolism (Gottschal et al.1979). If the relationship between growth rate/substrate concentration, determined by the parameters $\mu_{\max }$ and $K_{s}$, are plotted, ranges of growth competition become graphically apparent and predictable (Veldkamp \& Jannasch 1972). This competitive behaviour based on the efficiency of substrate utilisation or other distinctive characteristics of $\mu_{\max }$-selected and $\mathrm{K}_{\mathrm{s}}$-selected organisms, is in principle the basis of Winogradski's early perception of 'zymogenous' and 'autochthonous' soil bacteria: the former outgrowing the latter under eutrophic conditions (high substrate levels), and vice versa under oligotrophic conditions (low substrate levels) (Jannasch \& Mateles 1974). The complexity of multiple-substrate- and/or multiple-nutrientlimited growth under natural conditions are discussed by Gottschal in this issue.

\section{Heterocontinuous systems}

The experimental advantage of a well defined chemostat for biochemical, physiological, and genetic studies in steady state cultures lies principally in the elimination of time dependency of growth. The required complete mixing and constancy of all physico-chemical parameters represent artificial growth conditions in a similar manner as those imposed by closed batch culture system and are unsuitable for the study of a number of microbial interactions as they occur under natural conditions. There are many reasons why, in ecologically oriented experi- 
ments, such constancy of a continuous 'open flow' system is undesirable. The rate of the microbial breakdown of a complex substrate, for instance, might be affected by the successive removal of the breakdown product through a secondary population and its particular spatial proximity to the primary population. Because of its characteristic selective effects, homocontinuous culture conditions prevent the study of such interactions.

The borderline between homo- and heterocontinuous systems is somewhat diffuse, and it is doubtful whether strict definitions serve a purpose. Two organisms may be maintained in a homocontinuous system, turning it heterocontinuous by leading to oscillations of the two populations, i.e. Dictyostelium discoideum preying on Escherichia coli growing on glucose (Tsuchiya et al. 1972). Damped oscillations were observed in more complex populations (Shuler et al. 1972) where Azotobacter vinelandii competes with $E$. coli for glucose, the former providing fixed nitrogen, and both being preyed upon by Tetrahymena pyriformis. Such food chain studies are especially susceptible to complications by wall growth and other apparatus effects and quickly become unpredictable. Much of this work is based on Gause's classic treatment of mathematical biology and ecology (1934, reprinted 1971).

It appears that, under natural conditions, populations of individual organisms are never in steady state: they are either increasing or decreasing (Jannasch 1974). The situation of an organism under natural conditions resides somewhere between those of the 'closed' batch culture and the 'open' continuous culture system. At most, there are semicontinuous conditions such as in the rumen or dental plaques, but the effect of microbial selection by complete mixing and removal of relatively slower growing organism is characteristically absent. Discontinuity of flow is one way to maintain the co-existence of ecologically and biotechnologically important populations in single stage culture vessels. Other ways are multi-stage continuous flow cultures with vessels of different volumes (dilution rates), incomplete mixing, feedback systems. etc. as discussed by Herbert (1961a).

If a physiological interdependency of metabolically different organisms exists, one speaks of "con- sortia'. Two or more members of such consortia interact metabolically as, for instance, by interspecies hydrogen transfer. The characteristic cell conglomerates often resist separation into pure cultures. Some organisms form conglomerates even in pure culture, such as Sphaerotilus or Leptothrix (Ordal \& Palmer 1964; Mulder \& Veen 1965) appear to require semi-batch culture conditions. This is specifically true for those that grow optimally at chemical interfaces in dense cell assemblages such as mats (Beggiatoa, lit. in Nelson et al. 1989) or veils (Thiovulum, lit. in Jannasch \& Mateles 1974). Controlled growth studies are inherently difficult with organisms requiring attachment to surfaces. Yet these organisms are prominent in many ecologically and biotechnologically important systems.

The heterogeneity of continuous culture populations can be maintained by discontinuous flow and incomplete mixing in single reactor systems as well as by multiple-vessel systems. Organisms with different growth rates will coexist in the presence of separate spatial niches. Such systems are not only used to mimic natural conditions but also to achieve optimal conversion rates of complex organic substrates. In view of the former, Bungay \& Bungay (1968) define cases of microbial commensalism, mutualism, competition, parasitism and predation. A fine example of enhancing the decomposition of an initially toxic mixture of industrial waste effluent by passing it through a multi-stage system imposing different retention times and strategically placed feedbacks was demonstrated by Abson \& Todhunter (1961).

Such empirically devised heterocontinuous systems not only involve mixed populations but also multiple substrates and may result in successive shifts of utilisation accompanied by a changing population predominance of one organism over another. Such systems were used extensively later in competition studies by Gottschal \& Kuenen (1979). At some point of complexity, heterocontinuous culture systems cross the borderline from theoretically conceived studies to those of empirically derived usefulness.

As mentioned above, the basic relationship between growth rate and concentration of the limiting substrate appears to be so fundamental to microbial 
growth kinetics that one of the authors (TE) has prepared a special discussion of the past and recent developments in this area.

\section{Growth rate versus substrate concentration: conflict between theory and experimental data}

\section{Early investigations and Monod's equation}

Prior to ca. 1940 investigation of growth in relation to nutrient concentration was difficult because both the selectivity and the sensitivity of analytical techniques to measure substrate concentrations were restricted and bacterial growth had to be determined via total cell counts which were tedious (Van Niel 1949; Dean \& Hinshelwood 1966). The few early investigations that can be found in the literature are all in agreement that the curve describing the relation between growth rate and concentration of the limiting nutrient already approached saturation values at very low substrate concentrations (Penford \& Norris 1912, for Bacillus typhosus growing on peptone; Dagley \& Hinshelwood 1938, for Aerobacter aerogenes growing on either glucose or phosphate). These authors suggested that the general course of the rate-concentration relationship followed an equation similar to a Langmuir adsorption isotherm.

It was only the new technique of measuring turbidity which permitted assessment of bacterial growth easily and quickly in liquid culture that allowed Monod (1942) to investigate the influence of the concentration of various sugars (glucose, mannitol, lactose) on the growth rate of $E$. coli and $B$. subtilis. Monod's data exhibited considerable scattering at low substrate concentrations and he was perfectly aware that choices could be made between different mathematical formulas for the concentration-growth rate relationship. The reasoning which made him propose the well-known relationship between the concentration of a carbon source and growth rate, $\mu(s)=\mu_{\max } s /\left(K_{s}+s\right)$ he commented on in a later review (Monod 1949) in the following way: "... relatively simple empirical laws are found to express conveniently the relation between exponential growth rate and concentration of an essen- tial nutrient. ... Several mathematical different formulations could be made to fit the data. But it is convenient and logical to adopt a hyperbolic equation: $R=R_{K} C /\left(C_{1}+C\right)$ similar to an adsorption isotherm or to the Michaelis equation." In the same review Monod also stressed that his proposal did not imply a relationship between the affinity constant $K_{s}\left(C_{1}\right)$ used in the growth model and the Michaelis-Menten constant, $K_{m}$.

\section{Alternative models}

In the last half century the concepts in microbial growth kinetics have been dominated by the ideas proposed by Monod (1942). However, the fact that Monod's data did not indisputably support his proposed mathematical formula gave rise to many more studies on the relationship between growth rate and substrate concentration. Whereas some investigators tried to acquire better experimental data to prove his suggestion, other researchers criticised it in that the hyperbolic curve approached the saturation level too slowly (Powell 1967). As a result of this, various alternative formulae or modifications of the Monod model have been proposed which were said to describe equally well or even better the experimental data (see for example Schulze \& Lipe 1964; Powell 1967; Shehata \& Marr 1971; Dabes et al. 1973; Koch \& Wang 1982; Westerhoff et al. 1982; Kooijman et al. 1991). Other studies led to the conclusion that the experimental data collected exhibited so much scatter that it was difficult, if not impossible, to statistically discriminate between the different models proposed (Rutgers et al. 1987, 1989; Owens \& Legan 1987; Senn et al. 1993). However, the basic concept of all these mathematical descriptions of microbial growth was always the same: the rate of growth was assumed to be in some way dependent on the extracellular concentration of a single growth-limiting substrate (for an exception see Droop 1973).

From 1950 onwards, numerous papers have been published where the relationship between growth rate and the concentration of a certain substrate for a microorganism was reported to obey the law of Monod, resulting in long lists of affinity constants, 
$\mathrm{K}_{\mathrm{s}}$ (reviewed in Button 1985; Owens \& Legan 1987). In spite of these efforts, this issue has not been resolved in a satisfactory way after more than 50 years of research. This is illustrated by the fact that affinity constants of $E$. coli growing on glucose may vary over more than three orders of magnitude, namely from $99 \mathrm{mg} \mathrm{l}^{-1}$ (Schulze \& Lipe 1964) to $68 \mu \mathrm{g} \mathrm{l}^{-1}$ (Shehata \& Marr 1971). Such large variations have frequently been explained by strain differences, whereas Koch \& Wang (1982) provided evidence that they might be a result of the growth history of the inoculum. The many different methods that have been used to determine the Monod affinity constants and some of their problems have been reviewed and discussed by Owens \& Legan (1987).

\section{Experimental problems}

Two fundamental problems have always hampered investigations which attempted to relate $\mu$ and s. The first has been the difficulty to directly determine the concentration of the carbon substrate in the range where it exhibits greatest influence on the specific growth rate (Powell 1967; Owens \& Legan 1987; Rutgers et al. 1991; Senn et al. 1993). In most growth experiments the low substrate concentrations were derived simply by dilution. Only rarely were steady-state concentrations of substrates measured directly. The second problem concerns adaptation of microbes to low growth rates and low substrate concentrations. Several authors have reported that during cultivation in chemostat culture the residual concentration of the growth-limiting substrate decreased slowly until a stable low concentration was achieved after a hundred or more volume changes (Höfle 1983; Rutgers et al. 1987; Senn et al. 1993). Cells which had been adapted to carbon-limited growth conditions in chemostat culture over an extended period of time were reported to exhibit considerably different kinetic properties to those that were cultivated under nutrient-sufficient conditions in batch culture. Both, an increasing affinity (lower $\mathrm{K}_{\mathrm{s}}$ ) for the substrate and a change in the maximum specific growth rate constant $\mu_{\max }$ have been observed (Shehata \& Marr 1971; Koch \& Wang 1982; Höfle 1983; Rutgers et al. 1987; Senn et al. 1993). Similarly, adaptation in the opposite direction, i.e. from oligotrophic to copiotrophic growth characteristics, is a common observation for bacteria isolated from seawater and transferred into media containing high substrate concentrations (Jannasch 1968). The change (increase) of the $\mu_{\max }$ exhibited by bacterial cells after several transfers in batch cultures has already been described by Dean \& Hinshelwood (1966) and was called 'training' of the cells. It has been suggested that such changes in growth characteristics might result from a selection of unstable mutants which have either acquired or lost multiple copies of for instance substrate transport proteins (Rutgers et al. 1987).

\section{Where do we go from here?}

All this evidence indicates that it is probably not possible to describe the kinetics of a bacterium with one single set of constants. Powell (1967) formulated this conflict in the following way: "The great defect of all formulae such as that of Monod is that they represent the growth rate as depending only on the instantaneous value of $s$... In fact, the growth rate at any given time $t$ depends not only on $s(t)$ but also on the history of the culture, in particular, on the way in which $\mathrm{s}$ has varied in the past. ... We can ask, not for a quite general formula for $\mu$ (s), but for a formula which is true under steady state conditions, when $\mu$ and $s$ have remained unchanged for a long time relative to the mean generation time of the organisms concerned."

The fact that cells exhibit different kinetic properties dependent on their history of growth, is consistent with the experience that the biochemical composition and metabolic capability of cells vary considerably with growth rate and growth conditions (Schaechter et al. 1958; Herbert 1961b). Such differences in cellular composition as a response to environmental growth conditions are well documented in the literature (reviewed in Harder \& Dijkhuizen 1983; Tempest et al. 1983). For example, many bacteria are able to replace low affinity/high capacity enzyme systems designed for growth under nutrient excess conditions with high affinity/low capacity enzyme systems when a nutrient becomes 
scarce (e.g., Harder \& Dijkhuizen 1983; Tempest et al. 1983). Adaptation to low nutrient levels is not achieved within a few generations. If cells pregrown at high substrate concentrations are inoculated into media with low concentrations, they will exhibit their low substrate affinity for considerable time. Hence, it is not surprising that kinetic studies performed with differently 'trained' cells of $E$. coli gave inconsistent data.

Perhaps we have to accept the fact that it may never be possible to describe the growth kinetics of a microorganism with a single set of constants. It will be of great interest, however, to study the scale of the feast and famine ends of an organism's kinetic properties, the physiological conditions and the time scale of such adaptive responses, and finally the fundamental molecular and genetic processes involved in these processes (discussed in Dykhuizen \& Hartl 1983). From the ecological point of view it will be a great step forward to be able to define quantitatively those properties that are so far generally described as oligotrophy and copiotrophy.

The above discussion as well as the comprehensive papers by Westerhoff et al. (1982) and Rutgers et al. (1991) clearly demonstrate that the theory of metabolic control is adding a new dimension to growth kinetics. It appears that we finally begin to understand the kinetics of the utilisation of carbon substrate mixtures (Egli et al., this issue). Furthermore, Rutgers et al. (1990) presented strong evidence that the rate of growth can be controlled by more than only one nutrient at the same time.

\section{Concluding remarks}

Historical perspectives have a definite purpose. The progress of science is never continuous. Instead, advances occur in leaps and bounds. And in these periods of rapid progress it happens that most the exciting discoveries are buried again during the excavation of new nearby treasure-troves. Therefore, later re-discoveries are common occurrences, and sometimes they lead to more profitable advances than the original discoveries. In this endeavour, those are clearly favoured who know the litera- ture in order to uncover the gems of earlier findings. It appears that the field of growth kinetics with all its aspects is in such a revival period. This symposium is hoped to be a primer to the renaissance of microbial growth kinetics in the 1990s.

\section{References}

Abson JW \& Todhunter KH (1961) Plant for continuous biological treatment of carbonisation effluents. Soc. Chem. Ind. Monograph (London) 12: 147-164

Bauchop T \& Elsden SR (1960) The growth of microorganisms in relation to their energy supply. J. Gen. Microbiol. 23: 457469

Beran K, Málek I, Streiblová E \& Lieblová J (1967) The distribution of the relative age of cells in yeast populations. In: Powell PO, Evans CGT, Strange RE \& Tempest DW (Eds) Microbial Physiology and Continuous Culture (pp 57-67). H.M.S.O., London

Bryson V (1952) Microbial selection II. The turbidostatic selector - a device for automatic isolation of bacterial variants. Science 116: 48-51

Buchner H, Longard K \& Riedlin G (1887) Ǔber die Vermehrungsgeschwindigkeit der Bacterien. Zentr. Bakt. Parasitenk. 2: $1-7$

Buchanan RE (1918) Life phases in a bacterial culture. J. Infec. Diseases 23: 109-125

Bungay HR \& Bungay ML (1968) Microbial interactions in continuous culture. Adv. Appl. Microbiol. 10: 269-290

Button DK (1985) Kinetics of nutrient-limited transport and microbial growth. Microbiol. Rev. 49: 270-297

Campbell A (1957) Synchronization of cell division. Bact. Rev. 21: 263-272

Contois DE (1959) Kinetics of bacterial growth: relationship between population density and specific growth rate of continuous cultures. J. Gen. Microbiol. 21: 40-50

Dabes JN, Finn RK \& Wilke CR (1973) Equations of substratelimited growth: the case for Blackman kinetics. Biotechnol. Bioeng. 15: 1159-1177

Dagley S \& Hinshelwood CN (1938) Physicochemical aspects of bacterial growth. Part I. Dependence of growth of Bacterium lactis aerogenes on concentration of medium. J. Chem. Soc. 1938: 1930-1936

Dean ACR \& Hinshelwood C (1966) Growth, Function and Regulation in Bacterial Cells. Clarendon Press, Oxford

Dean ACR \& Rogers PL (1967) The cell size and macromolecular composition of Aerobacter aerogenes in various systems of continuous culture. Bioc. Biop. 148: 267-279

Dobell C (1932) Antony van Leeuwenhoek and his 'little animals'. Reprinted by Dover Publications, Inc. New York, 1960

Dykhuizen DE \& Hartl DL (1983) Selection in chemostats. Microbiol. Rev. 47: 150-168 
Droop MR (1973) Some thoughts on nutrient limitation in algae. J. Phycol. 9: 264-272

Egli T, Lendenmann U \& Snozzi M (1993) Kinetics of microbial growth with mixtures of carbon sources. Antonie van Leeuwenhoek (this issue)

Fencl Z (1963) A uniform system of basic symbols for continuous cultivation of microorganisms. Folia Microbiol. 8: 192-194

Gause GF (1971) The Struggle for Existence. Dover Publ., New York

Goldman JC (1977) Steady state growth of phytoplankton in continuous culture: comparison of internal and external nutrient equations. J. Phycol. 13: 251-258

Gorini L \& Maas W/K (1957) The potential for the formation of a biosynthetic enzyme in Escherichia coli. Biochim. Biophys. Acta (Amst.) 25: 208-209

Gorini L (1960) Antagonism between substrate and repressor in controlling the formation of a biosynthetic enzyme. Proc. Nat. Acad. Sci. (Wash.) 46: 682-690

Gottschal JC, de Vhies S \& Kuenen JG (1979) Competition between the facultatively chemotrophic Thiobacillus A2, and obligately chemolithotrophic Thiobacillus and a heterotrophic spirillum or inorganic and organic substrates. Arch. Microbiol. 121: 241-249

Gottschal JC (1993) Growth kinetics and competition - some contemporary comments. Antonie van Leeuwenhoek (this issue)

Harder W \& Veldkamp H (1971) Competition of marine psychrophilic bacteria at low temperatures. Antonie van Leeuwenhoek. 37: 51-63

Harder W \& Dijkhuizen L (1983) Physiological responses to nutrient limitation. Ann. Rev. Microbiol. 37: 1-23

Herbert D (1958) Continuous culture of microorganisms; some theoretical aspects. In: Máeek I (Ed) Continuous Cultivation of Microorganisms (pp 45-52). Czech. Acad. Sci., Prague

- (1961a) A theoretical analysis of continuous culture systems. Soc. Chem. Ind. Monograph (London) 12: 21-53

- (1961b) The chemical composition of mircro-organisms as a function of their environment. In: Meynell GG \& Gooder H (Eds) Microbial Reaction to Environment, 11th Sympos. Soc. Gen. Microbiol (pp. 391-416). Cambridge Univ. Press, London

Herbert D, Elsworth R \& Telling RC (1956) The continuous culture of bacteria: a theoretical and experimental study. J. Gen. Microbiol. 14: 601-622

Hinshelwood CN (1946) The Chemical Kinetics of the Bacterial Cell. Oxford University Press

Höfle MG (1983) Long-term changes in chemostat cultures of Cytophaga johnsonae. Appl. Environ. Microbiol. 46: 10451053

Jannasch HW (1965) Starter populations as determined under steady state conditions. Biotech. Bioeng. 7: 279-28

- (1968) Growth characteristics of heterotrophic bacteria in seawater. J. Bacteriol. 95: 722-723

- (1969) Estimations of bacterial growth rates in natural waters. J. Bacteriol. 99: 156-160

- (1974) Steady state and the chemostat in ecology. Limnol. \& Oceanogr. 19: 716-720
Jannasch HW \& Mateles RI (1974) Experimental bacterial ecology in continuous culture. Adv. Microb. Physiol. 11: 165 -212

Kell DB, van Dam K \& Westerhoff HV (1989) Control analysis of microbial growth and productivity. In: Baumberg $\mathrm{S}$, Hunter IS \& Rhodes PM (Eds) Microbial Products: New Approaches. Soc. Gen. Microbiol. Symp. 44 (pp 61-93). Cambridge University Press

Kjeldgaard NO, Maaløe O \& Schaechter M (1958) The transition between different physiological stages during balanced growth of Salmonella typhimurium. J. Gen. Microbiol. 19: $607-616$

Koch AL \& Wang CH (1982) How close to the theoretical diffusion limit do bacterial uptake systems function? Arch. Microbiol. 131: 36-42

Kooijman SALM, Muller EB \& Stouthamer AH (1991) Microbial growth dynamics on the basis of individual budgets. Antonie van Leeuwenhoek 60: 159-174

Kubitschek HE (1970) Introduction to Research with Continuous Culture. Prentice Hall, Englewood Cliffs, NY

Lamanna C (Ed) (1963) Endogenous Metabolism with Special Reference to Bacteria. Ann. N.Y. Acad. Sci. 102: 515-793

Lamanna C \& Malette MF (1959) Basic Bacteriology. Williams \& Wilkins, Baltimore

Lark KG (1960) Studies on the mechanism regulating periodic DNA synthesis in synchronized cultures of Alcanigenes fecalis. Biochim. Biophys. Acta (Amst.) 45: 121-132

Magasanik B, Magasanik AK \& Neidhardt FC (1959) Regulation of growth and composition of the bacterial cell. In: Sympos. on Regulation of Cell Metabolism (pp 334-349). Ciba Foundation, London

Málek I \& Fencl Z (Eds) (1966) Theoretical and Methodological Basis of Continuous Culture of Microorganisms. Czech. Acad. Sci., Prague, and Academic Press, London

Málek I (1958) Continuous Cultivation of Microorganisms. Czech. Acad. Sci., Prague

Mallette MF (1963) Validity of the concept of energy maintenance. In: Lamanna C (Ed) (1963) Endogenous Metabolism with Special Reference to Bacteria (pp 521-535). Ann. N.Y. Acad. Sci. 102

Marr AG, Nilson EH \& Clark DJ (1963) The maintenance requirements of Escherichia coli. In: Lamanna C (Ed) (1963) Endogenous Metabolism with Special Reference to Bacteria (pp 536-548). Ann. N.Y. Acad. Sci. 102

Monod J (1942) Recherches sur la Croissance des Cultures Bactériennes. Hermann \& Cie., Paris

- (1949) The growth of bacterial cultures. Annu. Rev. Microbiol. 3: 371-394

- (1950) La technique de culture continue; theorie and applications. Ann. Inst. Pasteur 79: 390-410

- (1959) Biosynthese eines Enzyms. Angew. Chem. 71: 685-708

Mulder EG \& van Veen WL (1965) Anreicherung von Organismen der Sphaerotilus-Leptothrix Gruppe. In: Schlegel HG (Ed) Anreicherungskultur und Mutantenauslese (pp 28-46). Gustav Fischer, Stuttgart

Müller M (1895) Ǔber den Einfluss von Fiebertemperaturen auf 
die Wachstumsgeschwindigkeit und die Virulenz des TyphusBacillus. Z. Hyg. Infektionskrankh. 20: 245-280

Myers L \& Clark LB (1944) Culture conditions and development of the photosynthetic mechanism. II. An apparatus for the continuous culture of Chlorella. J. Gen. Physiol. 28: 103-112

Novick A \& Szilard L (1950a) Description of the chemostat. Science 112: 715-716

- (1950b) Experiments with the chemostat on spontaneous mutations of bacteria. Proc. Nat. Acad. Sci. (Wash.) 36: 708-719

Novick A (1958) Genetic and physiological studies with the chemostat. In: Málek A (Ed) Continuous Cultivation of Microorganisms. Czech. Acad. Sci., Prague

Owens JD \& Legan JD (1987). Determination of the Monod substrate saturation constant for microbial growth. FEMS Microbiol. Rev. 46: 419-432

Pardee AB (1961) Response of enzyme synthesis and activity of environment. In: Meynell GG \& Gooder H (Eds) Microbial Reaction to Environment, 11th Sympos. Soc. Gen. Microbiol (pp. 19-40). Cambridge Univ. Press, London

Penfold W \& Norris D (1912) The relation of concentration of food supply to generation time of Bacteria. J. Hyg. 12: 527-531

Perret CG (1960) A kinetic model of a growing bacterial population. J. Gen. Microbiol. 11: 19-40

Pfennig N \& Jannasch HW (1962) Biologische Grundfragen bei der homokontinuierlichen Kultur von Mikroorganismen. Ergebnisse der Biologie 25: 93-135

Pirt SJ (1975) Principles of Microbe and Cell Cultivation. John Wiley \& Sons, New York

Powell EO (1967) The growth rate of microorganisms as a function of substrate concentration. In: Powell PO, Evans CGT, Strange RE \& Tempest DW (Eds) Microbial Physiology and Continuous Culture (pp 34-56). H.M.S.O., London

Powell EO, Evams CGT, Strange RE \& Tempest DW (1967) Microbial Physiology and Continuous Culture. H.M.S.O., London

Ricica J (1966) Technique of continuous laboratory cultivation. In: Málek I \& Fencl Z (Eds) (1966) Theoretical and Methodological Basis of Continuous Culture of Microorganisms (pp 155-314). Czech. Acad. Sci., Prague, and Academic Press, London

Rosenberger RF \& Elsden SR (1960) The yields of Streptococcus faecalis grown in continuous culture. J. Gen. Microbiol. 22: 726-739

Rutgers M, Teixeira de Mattos MJ, Postma PW \& van Dam K (1987) Establishment of the steady state in glucose-limited chemostat cultures of Klebsiella pneumoniae. J. Gen. Microbiol. 133: 445-453

Rutgers M, Balk PA \& van Dam K (1989) Effect of concentration of substrates and products on the growth of Klebsiella pneumoniae in chemostat cultures. Biochim. Biophys. Acta 977: 142-149

- (1990) Quantification of multiple-substrate controlled growth: simultaneous ammonium and glucose limitation in chemostat cultures of Klebsiella pneumoniae. Arch. Microbiol. 153: 478-484

Rutgers M, van Dam K \& Westerhoff HV (1991) Control and thermodynamics of microbial growth. Rational tools for bioengineering. CRC Crit. Rev. Biotechnol. 11: 367-395

Schaechter M, Maaløe O \& Kjeldgaard NO (1958) Dependency on medium and temperature of cell size and chemical composition during balanced growth of Salmonella typhimurium. J. Gen. Microbiol. 19: 592-606

Schlegel HG \& Jannasch HW (1967) Enrichment cultures. Ann. Rev. Microbiol. 21: 49-70

Schmidt RR \& King KW (1961) Metabolic shifts during synchronous growth of Chlorella pyrenoidosa. Biochem. Biophys. Acta (Amst.) 47: 391-392

Schulze KL \& Lipe RS (1964) Relationship between substrate concentration, growth rate, and respiration rate of Escherichia coli in continuous culture. Arch. Mikrobiol. 48: 1-20

Senn H, Lendenmann U, Snozzi M, Hamer G \& Egli T (1993) The growth of Escherichia coli in glucose-limited cultures: a reexamination of the kinetics. Biochim. Biophys. Acta (submitted)

Shehata TE \& Marr AG (1971) Effect of nutrient concentration on the growth of Escherichia coli. J. Bacteriol. 107: 210-216

Shindala A, Bungay HR, Krieg NR \& Culbert K (1965) Mixed culture interactions I. Commensalism of Proteus vulgaris with Saccharomyces cerevisiae in continuous culture. J. Bacteriol. 89: 693-696

Shuler ML, Aris R \& Tsuchiya HM (1972) Hydrodynamic focusing and electronic cell-sizing techniques. Appl. Microbiol. 24: 384-388

Stephenson M (1949) Growth and nutrition. In: Bacterial Metabolism, 3rd ed. (pp 159-178). Longmans, Green \& Co., London

Tempest DW (1970) The continuous cultivation of microorganisms. 1. Theory of the chemastat. In: Norris JR \& Ribbons DW (Eds) Methods in Microbiology, Vol 2 (pp 259-276). Academic Press, London

Tempest DW, Herbert D \& Phipps PJ (1967) Studies on the growth of Aerobacter aerogenes at low dilution rates in a chemostat. In: Powell PO, Evans CGT, Strange RE \& Tempest DW (Eds) Microbial Physiology and Continuous Culture (pP 240-254). H.M.S.O., London

Tempest DW, Neijssel OM \& Zevenboom W (1983) Properties and performance of microorganisms in laboratory culture; their relevance to growth in natural ecosystems. Symp. Soc. Gen. Microbiol. 34: 119-152

Tsuchiya HM, Drake JF, Jost JL \& Fredrickson AG (1972) Preditor-prey interactions of Dictyostelium discoideum and Escherichia coli in continuous culture. J. Bacteriol. 110: 11471153

Van Niel CB (1949) The kinetics of growth of microorganisms. In: Parpart ED (Ed) The Chemistry and Physiology of Growth (pp 91-102). Princeton Univ. Press

Veldkamp H (1976) Continuous Culture in Microbial Physiology and Ecology. Meadowfield Press, Durham, UK

Veldkamp H \& Jannasch HW (1972) Mixed culture studies with the chemostat. J. Appl. Biotechnol. 22: 105-123

Ward HM (1895) On the biology of Bacillus ramosus (Fraenkel), a Schizomycete of the River Thames. Proc. R. Soc. (London) 58: $265-468$ 
Westerhoff HV, Lolkema JS, Otto R \& Hellingwerf KJ (1982) Thermodynamics of growth. Non-equilibrium thermodynamics of bacterial growth. The phenomenological and mosaic approach. Biochim. Biophys. Acta. 683: 181-220

Westerhoff HV, van Heeswijk W, Kahn D \& Kell DB (1991) Quantitative approaches to the analysis of the control and regulation of microbial metabolism. Antonie van Leeuwenhoek 60: 193-207

Williamson DH \& Scopes AW (1961) Synchronization of division in cultures of Saccharomyces cerevisiae. In: Meynell GG \& Gooder H (Eds) Microbial Reaction to Environment, Symp.
Soc. Gen. Microbiol (pp 217-242). Cambridge Univ. Press, London

Wilkinson JF \& Munro ALS (1967) The influence of growth limiting conditions on the synthesis of possible carbon and energy storage polymers in Bacillus megaterium. In: Powell PO, Evans CGT, Strange RE \& Tempest DW (Eds) Microbial Physiology and Continuous Culture (pp 173-185). H.M.S.O., London

Winslow C-EA \& Walker HH (1939) The earlier phases of the bacterial culture cycle. Bacteriol. Rev. 3: 147-153 